DOMINIKA PLUTA 1 (1) https://orcid.org/0000-0001-6246-9566

JEDDREJ SIUTA ${ }^{2}$ ๑ https://orcid.org/0000-0002-4797-1387

MIKOEAJ JAN CZERBAK 3 @ https://orcid.org/0000-0002-8937-2155

TADEUSZ DOBOSZ ${ }^{1}$ ๑ https://orcid.org/0000-0003-0413-9109

${ }^{1}$ Zakład Technik Molekularnych Katedry Medycyny Sądowej Uniwersytetu Medycznego we Wrocławiu

${ }^{2}$ Zakład Medycyny Sądowej Katedry Medycyny Sądowej Uniwersytetu Medycznego we Wrocławiu

${ }^{3}$ University of Bradford (UK) School of Life Sciences

\title{
Mokre preparaty muzealne - konserwacja i receptury
}

\section{ABSTRACT}

Wet museum exhibits - conservation and recipes

Due to the uniqueness of wet museum exhibits, there is often a shortage of adequately trained people to carry out conservation work in museum units. Unfortunately, in many cases, the museum exhibits require immediate work. There is usually a visible loss of preservative fluid, or no fluid at all if it has evaporated. Moreover, chipped lids and damaged jars frequently occur. Some exhibit labels are damaged or torn off. Some items have been exhibited incorrectly, but when they are transferred to a new vessel or the fluid is replaced, they gain added value. Although there is a great need for conservation work, many museologists fail to carry it out. A significant problem is the absence of unified conservation procedures or guidelines which could be applied for these types of cases. This paper includes conservation formulas and recipes used at the Molecular Techniques Unit. The authors of this paper hope that it will be helpful to all those who deal with preserving wet museum exhibits.

Keywords: conservation, medical museums, wet exhibits

Słowa kluczowe: konserwacja, muzea medyczne, mokre preparaty 


\section{Wstęp}

Mokre preparaty muzealne to wyjątkowy rodzaj eksponatów, nie tylko ze względu na unikatowość, ale także niekonwencjonalny sposób konserwacji. Staje się to powodem wielu problemów w wypadku ich uszkodzenia - często w jednostkach nie ma odpowiednio przeszkolonych osób do wykonania koniecznych zabiegów konserwacyjnych. Ponadto niejednokrotnie brakuje procedur i wytycznych, dzięki którym można uratować muzealia. Poniższa publikacja zawiera przepisy i receptury konserwacyjne używane w Zakładzie Technik Molekularnych. Większość z nich to procedury „zastałe”, nieznanego autorstwa, „od zawsze” stosowane w muzeum. Inne są rezultatem wprowadzonych przez nas modyfikacji wynikających z wieloletniej praktyki lub są owocem naszych własnych przemyśleń i inwencji, potwierdzonych długotrwałą obserwacją ich skutków. Nierzadko pracownicy jednostki zetknęli się z różnymi eksponatami o różnorodnych potrzebach odświeżenia. Wszystkie jednak prace rozpoczynają się od analizy, co należy zrobić i jak tego można dokonać. Po wstępnej ocenie słoja - czy jest dobrze dobrany (nie za mały lub za duży), czy preparat jest dobrze wyeksponowany, czy naczynie nie jest wyszczerbione lub pęknięte - należy oszacować stan i ubytki płynu konserwującego. Kolejnym krokiem jest jego uzupełnienie bądź też wymiana i zamknięcie naczynia wybraną metodą. $\mathrm{Na}$ końcu należy pamiętać o opisaniu eksponatu wraz z zostawieniem informacji, kto i kiedy dokonał konserwacji, czasem też (gdy dokonano zmian) - jaką metodą. Szczegółowy opis powyższych etapów przedstawiono w dalszym ciągu tego tekstu.

\section{Przygotowanie do wymiany płynu}

Przed przystąpieniem do wyboru odpowiedniego płynu należy podjąć decyzję dotyczącą słoja, w którym umieszczony zostanie preparat. Często zdarza się, że stare naczynie jest pęknięte lub o wiele za duże (lub za małe) i wtedy należy je wymienić na inne. Kiedy nie ma takiej potrzeby, można poprzestać na wymyciu i oczyszczeniu pojemnika. Należy pamiętać, że jeżeli tkanka zawiera dużo tłuszczu lub powietrza (może pływać), to należy przymocować ją do szklanej płytki lub zawiesić ciężarek z niekorodującego materiału.

\section{Rodzaje słojów}

Stoje laboratoryjne z zakręcanym plastikowym wieczkiem (il. Ia) zwykle przeznacza się do przechowywania odczynników chemicznych. Niestety, mimo niskiego kosztu i łatwości otwierania trwałość plastikowych wieczek jest nieznana. Ponadto tak zakonserwowane eksponaty nie wydają się eleganckie.

Słoje z gwintem, z metalowa zakrętka (il. Ib), rzadko spotykane w muzeum, są przeznaczone głównie do użytku kuchennego. Łatwo dostępne, elastyczne i łatwe do otwierania. Niestety, metalowe zakrętki korodują, a ich wygląd również nie jest elegancki. 
Stoiki kuchenne ,do przypraw” (il. Ic) z elastycznym zatrzaskiwanym wieczkiem są tanie i łatwo dostępne, pewnie dlatego często spotykane w muzeach, aczkolwiek przeważnie używane są w kuchni. Występują jedynie problemy ze zdobyciem zapasowych wieczek.

Słoiki kuchenne Wecka (il. Id) są przeznaczone na domowe przetwory, charakteryzują się masywnym szklanym wieczkiem i grubą gumową uszczelką z ,języczkiem”. Stosowane od ponad 100 lat ostatnio są wypierane przez słoiki twist. Niestety, gumowa uszczelka nie cechuje się dużą trwałością. Dodatkowo ich kuchenny wygląd nie bardzo pasuje do muzealnej zawartości.

Słoje zamykane na klamrę ze śruba (il. Ie) - rzadko spotykana, kosztowna odmiana słoi Wecka. Bywają dość skomplikowane, występują trudności w wypadku konieczności znalezienia zamiennika zużytych uszczelek.

Słoje zamykane na szlif (il. If), stosowane od początku muzealnictwa, są drogie, ale doskonale pełnią swoją funkcję. Wieczka indywidualnie docierano do słoi, co oznacza, że stanowią niewymienny komplet. Niebywałą zaletą jest ich ogromna szczelność - na ponad 100 lat (jeżeli szlif posmarowany był wazeliną). Wadą jest spora cena, a po długim przechowywaniu mogą wystąpić problemy z ich otwarciem.

Słoje z kołnierzem (il. Ig) to rzadko spotykany słój typu „rosyjskiego”, charakteryzujący się wywiniętym kołnierzem, do którego przykleja się pokrywkę. Ich odmianą jest wersja „rozkloszowana”, wewnątrz wywiniętego kołnierza znajduje się szkiełko bez szlifu, zazwyczaj uszczelniane lakiem. Słoje z kołnierzami zwykle są szczelne, jeżeli zamykano je starannie. Łatwe do zamykania, lecz bardzo kłopotliwe przy otwieraniu.

Zupetna nowościa sa pojemniki wykonane z pleksiglasu (il. Ih), bardzo modne i efektowne, lecz o nieznanej trwałości. Płyn konserwujący może wyparowywać z takiego naczynia przez hydrofilne ścianki, a otwarcie pojemnika w celu uzupełnienia lub wymiany płynu stanowi spory problem. Rozwiązaniem może być wywiercenie otworu wiertarką, przy użyciu bardzo cienkiego wiertła, a następnie pobranie płynu albo jego uzupełnienie strzykawką. Powstały otwór może zostać zaklejony kroplą gorącego laku lub silikonem.

\section{Wymiana płynu}

Przy wymianie lub też uzupełnieniu płynu konserwującego największym kłopotem jest jego identyfikacja - aby zastosować taki sam lub możliwie podobny, konserwator często kieruje się jego zapachem lub też w ciemno uzupełnia najbardziej lotnym składnikiem (etanolem). Duży kłopot sprawiają również płyny ciemne i mętne, które przed uzupełnieniem warto jest odbarwić węglem aktywnym bądź przesączyć - zdarzają się jednak przypadki, kiedy powyższe zabiegi nie skutkują i należy wymienić stary płyn na nowy. Poniżej przedstawione zostaną rodzaje płynów muzealnych wraz z autorskimi recepturami niektórych z nich (il. II). 


\section{Rodzaje płynów muzealnych}

Plyn Carnoya - zastosowany po raz pierwszy prawdopodobnie na przełomie XVIII i XIX wieku, obecnie składa się z alkoholu absolutnego (etanolu lub metanolu), chloroformu i kwasu octowego lodowatego zmieszanych w stosunku objętościowym $60: 30: 10$. Dobrze konserwuje determinanty antygenowe tkanek, jest więc polecany do celów immunologicznych, niestety, kwaśny odczyn może być szkodliwy dla DNA, na szczęście dla RNA w mniejszym stopniu'.

Plyn karbolowy (glicerynowo-fenolowy) - opracowany najprawdopodobniej w 1876 roku przez dra Laskowskiego, składał się z kwasu karbolowego (fenolu) rozpuszczonego w glicerynie. Dobrze zachowuje elastyczność i kolor preparatu, przyjazny dla DNA, bardzo powoli odparowuje nawet przy niecałkowicie szczelnym zamknięciu. Mimo tych zalet fenol jest trujący, łatwopalny i powoduje bardzo poważne oparzenia, a gotowy płyn konserwujący ma bardzo przenikliwą woń ${ }^{2}$. Oparzenie fenolem powoduje zbielenie naskórka, należy wówczas przez kilka minut płukać skórę letnią wodą, do ustąpienia zbielenia.

\section{Autorska receptura plynu karbolowego:}

Roztopić 30 g fenolu w łaźni wodnej, połączyć ze $100 \mathrm{ml}$ glicerolu ogrzanego do $+80^{\circ} \mathrm{C}$, starannie wymieszać, a następnie rozmieszać w $900 \mathrm{ml}$ gliceryny.

Plyn formalinowy (formaldehyd, aldehyd mrówkowy, metanal) - formalina została wykryta w 1858 roku przez Aleksandra Butlerowa, opisana w 1869 roku przez Augusta Wilhelma von Hoffmanna, a po raz pierwszy użyta do celów bakteriobójczych i w muzealnictwie na przełomie XIX i XX stulecia. W muzealnictwie używa się jej w stężeniu 1-3\%. Ma silne właściwości bakteriobójcze, pozwala zachować elastyczność tkanek. Niestety, jest rakotwórcza, nadaje preparatom szarą barwę, jest nieprzyjazna dla DNA (sieciuje łańcuchy helisy, uniemożliwiając PCR), czasami polimeryzuje, powodując wytrącenie się białych szpecących kłaczków, a przy dostępie powietrza utlenia się do kwasu mrówkowego, co prowadzi do uszkodzenia preparatu i fragmentuje DNA. Nie rekomenduje się użycia formaliny do sporządzania nowych preparatów, natomiast można użyć tego płynu do dolewek (lub wymiany) starych płynów konserwujących formalinowych, które łatwo rozpoznać po zapachu1.

Autorska receptura plynu formalinowego:

Zmieszać 23\% etanol z 10\% glicerolem i 1\% formaliną (500 $\mathrm{ml}$ wody, $250 \mathrm{ml}$ etanolu $95 \%$ lub $258 \mathrm{ml}$ etanolu $92 \%, 100 \mathrm{ml}$ glicerolu i $38 \mathrm{ml}$ formaliny 38\% doprowadzić do $\mathrm{pH}=7,5$ za pomocą $\mathrm{NaOH}$, dopełnić do $1000 \mathrm{ml}$ wodą).

Plyn klasyczny. Jest to najczęściej stosowany w naszym muzeum płyn konserwujący. W naszym muzeum stosowano go od kilkudziesięciu lat, nie znamy jego twórców. Ważne, że jeżeli używa się go do sporządzania nowych eksponatów, a masa tkanki jest duża, to po tygodniu należy go wymienić na nowy, ponieważ stężenie etanolu spada w nim poniżej minimalnego dla konserwacji stężenia. Płyn ten można też stosować jako

${ }^{1}$ A. Korga, Trudności w wykorzystaniu tkanek $z$ archiwalnych bloczków parafinowych $w$ badaniach ekspresji RNA, „Postępy Higieny i Medycyny Doświadczalnej” 2007, nr 61, s. 151-154.

${ }^{2}$ R.W. Gryglewski, Zygmunt Laskowski i jego technika tworzenia preparatów anatomicznych, „Przegląd Lekarski” 2015, nr 72, s. 707. 
dolewkę (uzupełniania ubytków) wielu innych płynów konserwujących, z wyjątkiem formalinowych (stosujemy go wtedy, gdy nie wyczuwamy zapachu formaliny po otwarciu słoika). Powinien mieć pH > 7,5, wówczas jest przyjazny dla materiału genetycznego $\mathrm{i}$ bezpieczny dla tkanki (prawie nigdy całkowicie nie wyparowuje).

Autorska receptura plynu klasycznego:

$33 \%$ etanol z 10\% glicerolem (330 ml etanolu absolutnego albo $350 \mathrm{ml}$ etanolu $95 \%$ i $100 \mathrm{ml}$ glicerolu dopełnić do $1000 \mathrm{ml}$ wodą, w razie potrzeby doprowadzić do $\mathrm{pH}=7,5$ za pomocą $\mathrm{NaOH})$.

Plyn Pampela stosowany jest jako pierwsza kąpiel tkanki przy sporządzaniu nowych preparatów. Chociaż przepisy prawne bardzo utrudniają tworzenie nowych eksponatów, podajemy poniżej dodatkowo przepis na wykonanie tego płynu, którego użycie zapewnia większą elastyczność oraz zmniejsza odbarwianie preparatu przez etanol ${ }^{3}$.

\section{Autorska receptura płynu Pampela:}

Dodać do siebie sześć objętości formaliny 35\%, 15 objętości etanolu 96\%, dwie objętości kwasu octowego lodowatego i 30 objętości wody destylowanej. Po 24 godzinach płyn Pampela wymienia się na płyn konserwujący z formaliną lub bez niej.

Ptyn konserwujacy Frederika Ruyscha. Frederik Ruysch (1638-1731), holenderski botanik i anatom, stosował płyn konserwujący będący wywarem roślinnym o nieustalonym składzie. Przypuszcza się, że Ruysch nastrzykiwał preparaty miksturą złożoną z cynobru, tlenku i siarczku rtęci oraz owczego tłuszczu, a potem zalewał $70 \%$ etanolem będącym wywarem ziaren czarnego pieprzu. W płynie tym od ponad 300 lat tkanki zachowują integralność i elastyczność oraz pierwotną barwę. W 1697 roku kolekcja Ruyscha została kupiona przez cara Piotra Wielkiego i przewieziona do Ermitażu. Dzisiejsza jej konserwacja sprawia ogromne problemy techniczne. Są prowadzone analizy próbek oryginalnego płynu, lecz jak na razie nie przyniosły one oczekiwanego rezultatu.

Roztwór Ruffera. Stosuje się go przy ratowaniu starych preparatów anatomicznych, w których płyn konserwujący całkowicie wyparował i tkanka kompletnie wyschła ${ }^{4}$.

Autorska receptura zmodyfikowanego $1 \%$ roztworu Ruffera:

W $500 \mathrm{ml}$ wody rozpuścić $\left.10 \mathrm{~g} \mathrm{Na}_{2} \mathrm{CO}_{3}\right\} \mathrm{H}_{2} \mathrm{O}$ albo $13 \mathrm{~g} \mathrm{Na}_{2} \mathrm{CO}_{3}-3 \mathrm{H}_{2} \mathrm{O}$ albo $2,3 \mathrm{~g}$ $\mathrm{Na}_{2} \mathrm{CO}_{3} \times 10 \mathrm{H}_{2} \mathrm{O}$ (nazwanego inaczej uwodnionym węglanem sodu), dodać $190 \mathrm{ml}$ etanolu 99\% (albo $200 \mathrm{ml}$ etanolu 95\% lub $207 \mathrm{ml}$ etanolu 92\%), $100 \mathrm{ml}$ 30\% perhydrolu i uzupełnić wodą do 1 litra. Ważne, aby przygotować tylko tyle roztworu, ile potrzeba, ponieważ jest nietrwały. W zmodyfikowanym roztworze Ruffera należy moczyć zmumifikowaną tkankę 1-7 dni, a następnie wymienić płyn Ruffera na płyn konserwujący $\mathrm{z}$ formaliną lub bez niej.

Solanka i syrop. Nasycona solanka bywała używana sporadycznie do konserwacji tkanek zwierzęcych. Dzisiaj stosuje się ją wyłącznie jako improwizację do doraźnego zabezpieczenia cennych okazów zwierząt, chociaż lepiej użyć do tego celu wódki, ponieważ w solance okazy tracą kolor i czasami twardnieją. Niektóre źródła podają, że do

${ }^{3}$ N. Winiarska, Konserwacja zagrożonych preparatów muzealnych i metoda nieniszczacej izolacji DNA z płynu konserwujacego, praca magisterska, UM, Wrocław 2014.

${ }^{4}$ K. Wilemska, M. Zieliński, M. Jasińska, M. Szynawa, M. Kucharzewski, Frederik Ruysch-życie i działalność medyczna, „Annales Academiae Medicae Silesiensis” 2012, nr 66, s. 91-92. 
konserwacji okazów roślinnych można użyć co najmniej 50\% nasyconego roztworu sacharozy, ale należy w to wątpić, jeżeli nie pasteryzowano lub gotowano preparatu, ponieważ kolonie pleśni mogą rosnąć nawet na bardzo skondensowanym syropie.

\section{Zamykanie preparatów muzealnych}

Jednym z najważniejszych etapów konserwacji mokrych preparatów muzealnych jest ich ponowne zamknięcie. Mimo dużej dostępności różnych materiałów służących do tego celu, ważne jest, żeby wybrać najtrwalszą metodę, która wytrzyma wiele lat. Ich opis, wraz z wadami, zaletami i instrukcją zamknięcia, przedstawiamy poniżej.

Zamknięcia na szlif (il. If). Tego typu zamknięcia stosowano od początku muzealnictwa, są drogie, ale doskonale pełnią swoją funkcję. Wieczka indywidualnie docierano do słoi, co oznacza, że stanowią niewymienny komplet. Największą ich zaletą jest szczelne zamknięcie na ponad 100 lat (jeżeli szlif posmarowano wazeliną). Niestety, to kosztowna metoda, ponadto po długim przechowywaniu mogą być duże kłopoty z ich otwarciem. Zamykanie: zmyć benzyną, ksylenem lub terpentyną resztki starej wazeliny, lekko ogrzać słój z zawartością (aby „zassał”), nasmarować szlif nową porcją wazeliny i założyć obrotowym ruchem wieczko.

Zamknięcie na bitum (il. Va). Historyczny, jeden z pierwszych (oprócz szlifów) typ zamknięcia. Klej może pochodzić z ropy naftowej (bitum, czyli asfalt) lub węgla (smoła). Górna krawędź słoja i szkiełko naokoło muszą być zeszlifowane, aby klej „złapał”. Początkowo klejono szkiełka na gorąco, ale wymagało to dużej wprawy i pośpiechu. Obecnie można kupić gęste bitumiczne kleje rozpuszczalnikowe (typu „Abizol”) lub wodne dyspersje bitumu, a także kity dekarskie, w których bitum jest wymieszany z gumą albo włóknami celulozy lub szkła, co zapewnia spoinie większą wytrzymałość i elastyczność. Zamykanie: zeskrobać i zmyć rozpuszczalnikiem resztki starego kleju, pokryć górną krawędź słoja farbą bitumową, nanieść masę dekarską, skleić, obciążyć odważnikiem ok. 1 kg, odstawić na tydzień. Po zamknięciu słoja bitumem dobrze jest spoinę wykończyć, tzn. pomalować farbą bitumową lub okleić.

Zamknięcie na silikon (il. Vb). Bezbarwny silikon akwariowy cechuje się dużą dostępnością i prostotą w nakładaniu. Ponadto jest tani i łatwy do usunięcia. Niestety, nie wiadomo, jaka jest jego trwałość przy użyciu do zamknięcia preparatu. Zamykanie: ostrym nożem usunąć resztki starego silikonu, nanieść cienką warstwę silikonu akwariowego (do klejenia akwariów), silnie docisnąć wieczko, obciążyć odważnikiem ok. 1 kg, odstawić na dobę.

Spoina z kleju montażowego (il. Vc). Jest to nowy typ kleju, używany w budownictwie i przy pracach domowych, tani i łatwy w stosowaniu. Niestety jest nietrwały (twardnieje i pęka), a więc źle chroni przed parowaniem płynu. Zamykanie: należy usunąć resztki starego kleju, nanieść nową warstwę kleju (rekomendujemy jednak jego zmianę na inny, asfaltowy lub silikonowy, w zależności od wieku eksponatu), silnie przycisnąć wieczko, obciążyć odważnikiem ok. $1 \mathrm{~kg}$, odstawić na odpowiedni dla typu kleju czas.

Uszczelnianie przy użyciu laku (il. Vd). Jest to stara, tradycyjna metoda zamykania pojemników muzealnych, ostatnio wyraźnie w zaniku. Z jej zalet warto wymienić dużą odporność na wilgoć, chemikalia i upływ czasu. Do jej wad należą: rozmiękanie 
przy kontakcie z tłuszczem pochodzącym z tkanki, wysoka cena laku, trudności techniczne i nieodporność na urazy mechaniczne. Zamykanie: a) Zamykanie na lak. Stopić lak (można użyć starych odprysków), nagrzać szkiełko i krawędź słoja gorącym powietrzem, posmarować krawędź szkiełka lakiem, ponownie ogrzać szkiełko i zmontować, zanim lak skrzepnie. b) Z doszczelnieniem lakiem. Pojemnik zakorkować lub przykleić wieczko innym klejem, odczekać aż stwardnieje. Następnie albo zalakować szczelinę, albo odwrócić pojemnik do góry dnem i zanurzyć w gorącym laku. Jeżeli słój jest prostopadłościenny, lakować czterokrotnie, po jednej krawędzi na raz, podtrzymując wieczko palcami, i odczekać 5 minut między każdą kolejną operacją.

Uszczelnianie błona zwierzęca (il. Ve). Jest to stary, stylowy, obecnie bardzo rzadko spotykany typ zamknięcia preparatów muzealnych. Cechuje się dużą trwałością i odpornością na zmiany temperatury. Niestety, dobrze chroni tylko przy braku uszkodzeń i nienagannym wykonaniu, DNA z błony może przeniknąć do płynu, wyschnięta błona jest twarda i trudna do rozcięcia, a świeże zwierzęce jelita i pęcherze są trudne do uzyskania. Zamykanie: zamknąć pojemnik, dobrać fragment świeżego zwierzęcego jelita lub pęcherza, naciągnąć na pojemnik i odstawić w suche miejsce, aby wysechł i skurczył się, zaciskając na wieczku i słoju. Świeże zwierzęce jelito lub pęcherz mogą być zastąpione workiem dializacyjnym o odpowiedniej średnicy, dobrze namoczonym przed założeniem, albo rurą izolacyjną termokurczliwą, używaną przez elektryków, a w ostateczności plastikową taśmą samoprzylepną.

Uszczelnianie sznurkiem, suchym lub smołowanym (il. Vf). Jest to rzadki, przestarzały typ zamknięcia, dosyć trwały i dobrze wyglądający, jednakże pracochłonny, wymagający wprawy i słabo chroniący przed parowaniem płynu. Zamykanie: zamknąć pojemnik, ciasno owinąć wilgotnym sznurkiem (kurczy się i zaciska podczas wysychania), oryginalnym lub podobnym. Zakładając ostatni zwój, przełożyć koniec pod pętlę, aby się zacisnęła przy pociągnięciu, odciąć luźny koniec. Natomiast jeżeli sznurek był smołowany, należy namoczyć go przed użyciem w bitumie rozpuszczalnikowym i odsączyć szmatą nadmiar, aby nie ściekał na słoik.

Uszczelnianie opaska z tkaniny lub papieru (il. Vg). Eksponaty w tym stylu były najbardziej popularne na przełomie XIX i XX stulecia. Metoda daje świetny wygląd, pasujący do epoki, oraz bardzo dużą trwałość. Wadą jest natomiast sama technika, trudna, wymagająca nie tylko sporej wprawy, ale także specjalnych narzędzi i materiałów. Zamykanie: zamknąć słój i założyć starą opaskę (lub wykonać inną tego samego rodzaju). Jeżeli materiał był smołowany, przed założeniem namoczyć go w rozpuszczalnikowym bitumie i odsączyć nadmiar, aby nie ściekał.

Uszczelnianie taśma samoprzylepna (il. Vh). Obecnie jest to najczęściej spotykany sposób wykańczania konserwowanych pojemników, niestety, odbierający im nieco ze staroświeckiego uroku. Tani, prosty w użyciu, skuteczny i estetyczny. Trwałość zależy od jakości taśmy, klej może po pewnym czasie stać się kruchy lub odwrotnie, zmięknąć i mazać się. Zamykanie: do oklejenia użyć bardzo podobnej taśmy (ponowne wykorzystanie tej samej jest niewskazane).

Uszczelnianie przez pomalowanie (il. Vi). Tak wykończone eksponaty wyglądają bardzo profesjonalnie, elegancko i nobliwie. Technika jest pracochłonna, wymaga wprawy, farba po długim czasie pęka i łuszczy się. Zamykanie: wielokrotnie nakładać 
pędzelkiem cienkie warstewki farby, pozwalając jej dobrze podeschnąć między kolejnymi malowaniami.

Uszczelnianie kitem szklarskim (il. Vj). Należy używać kitu do drewna (żółtego), a nie miniowego, do metalu (czerwonego). Niebywałą zaletą metody jest szczelność, wadą natomiast pracochłonność i możliwość pękania kitu po dłuższym czasie. Zamykanie: zamknąć słój i okitować spoinę kitem szklarskim, pozwolić kitowi na podeschnięcie, wygładzić lekko naoliwionym ostrzem noża. Jeżeli kit jest stary i zbyt twardy, można spróbować go uelastycznić, rozgniatając palcami pod strumieniem gorącej wody.

Uszczelnianie parafina lub woskiem pszczelim (il. Vk). Ten typ uszczelniania jest rzadko stosowany, mimo niskiej ceny, prostoty techniki i szczelności. Wadą jest brzydki, nieprofesjonalny wygląd. Zamykanie: zamknąć słój (wskazówki są podane na innych przeźroczach). Uszczelnić, malując woskiem lub parafiną albo nakapując ją z płonącej świecy.

Kleje do wieczek. Oprócz już opisanych: laku, kitu, silikonu, kleju montażowego oraz substancji smolistych (smoły i asfaltu), szklane wieczka bywały przyklejane mieszaniną twarogu i wody amoniakalnej oraz gorącymi klejami na bazie wosku pszczelego, balsamu kanadyjskiego i innych żywic oraz kalafonii.

Etykiety z opisem preparatu. Powinny zawierać dane o osobie sporządzającej i dacie sporządzenia eksponatu, jego pochodzeniu i opis. Etykiety te należy zaparafinować, a dodatkową, napisaną ołówkiem, skrótową etykietkę wrzucić do słoja.

\section{Podsumowanie}

Należy pamiętać, iż podczas konserwacji ratuje się, w miarę możliwości, wszystkie elementy eksponatu: preparat, słój, etykietę, elementy zamknięcia oraz resztki płynu konserwującego. Jeżeli ubytki są małe, identyfikuje się rodzaj płynu i uzupełnia „na oko” (albo raczej „,na nos”) tylko najlotniejsze jego składniki, np. czystym etanolem. Jeśli natomiast płyn jest mętny, odwirowuje się go lub przesącza. Gdy płyn jest ciemny, odbarwia się go węglem aktywnym, gdy to nie pomaga, można dodać nadtlenku wodoru do końcowego stężenia 3\% (zabieg ten jest nieprzyjazny dla DNA).

\section{Bibliografia}

Gryglewski R.W., Zygmunt Laskowski i jego technika tworzenia preparatów anatomicznych, „Przegląd Lekarski” 2015, nr 72, s. 707.

Korga A., Trudności w wykorzystaniu tkanek z archiwalnych bloczków parafinowych $w$ badaniach ekspresji RNA, „Postępy Higieny i Medycyny Doświadczalnej” 2007, nr 61, s. 151-154.

Wilemska K., Zieliński M., Jasińska M., Szynawa M., Kucharzewski M., Frederik Ruysch-życie i działalność medyczna, „Annales Academiae Medicae Silesiensis” 2012, nr 66, s. 91-92.

Winiarska N., Konserwacja zagrożonych preparatów muzealnych i metoda nieniszczacej izolacji DNA z płynu konserwujacego, praca magisterska, UM, Wrocław 2014. 
Dominika Pluta et al.
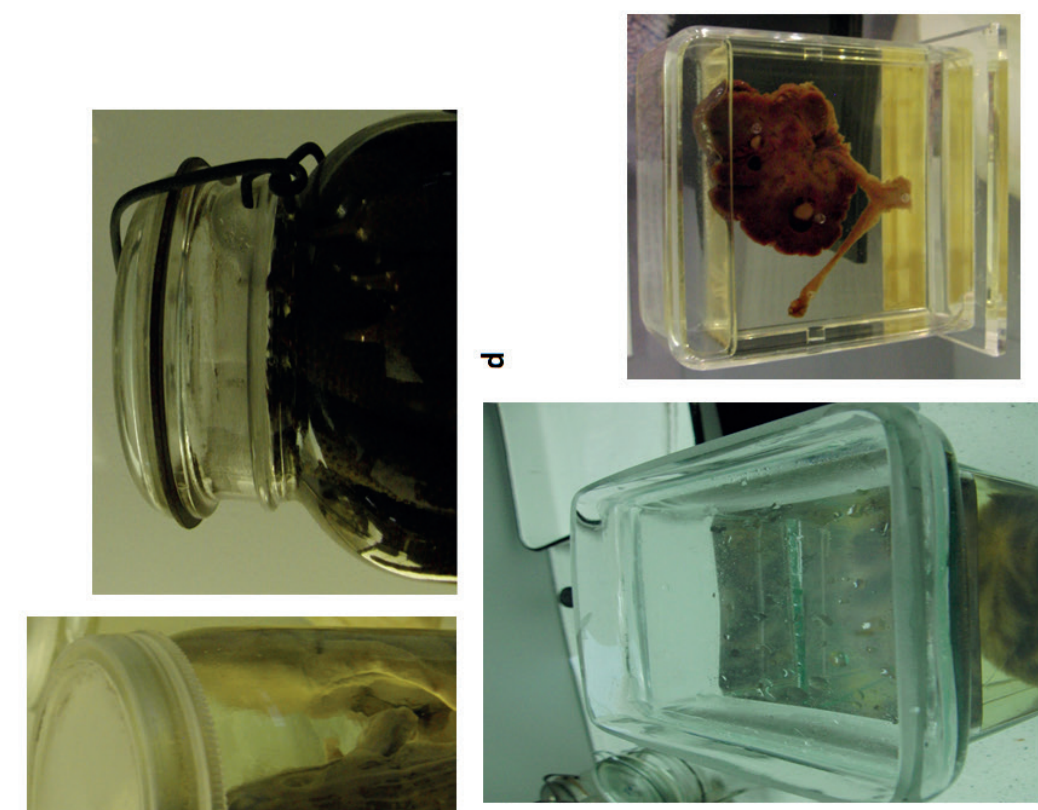

离苍
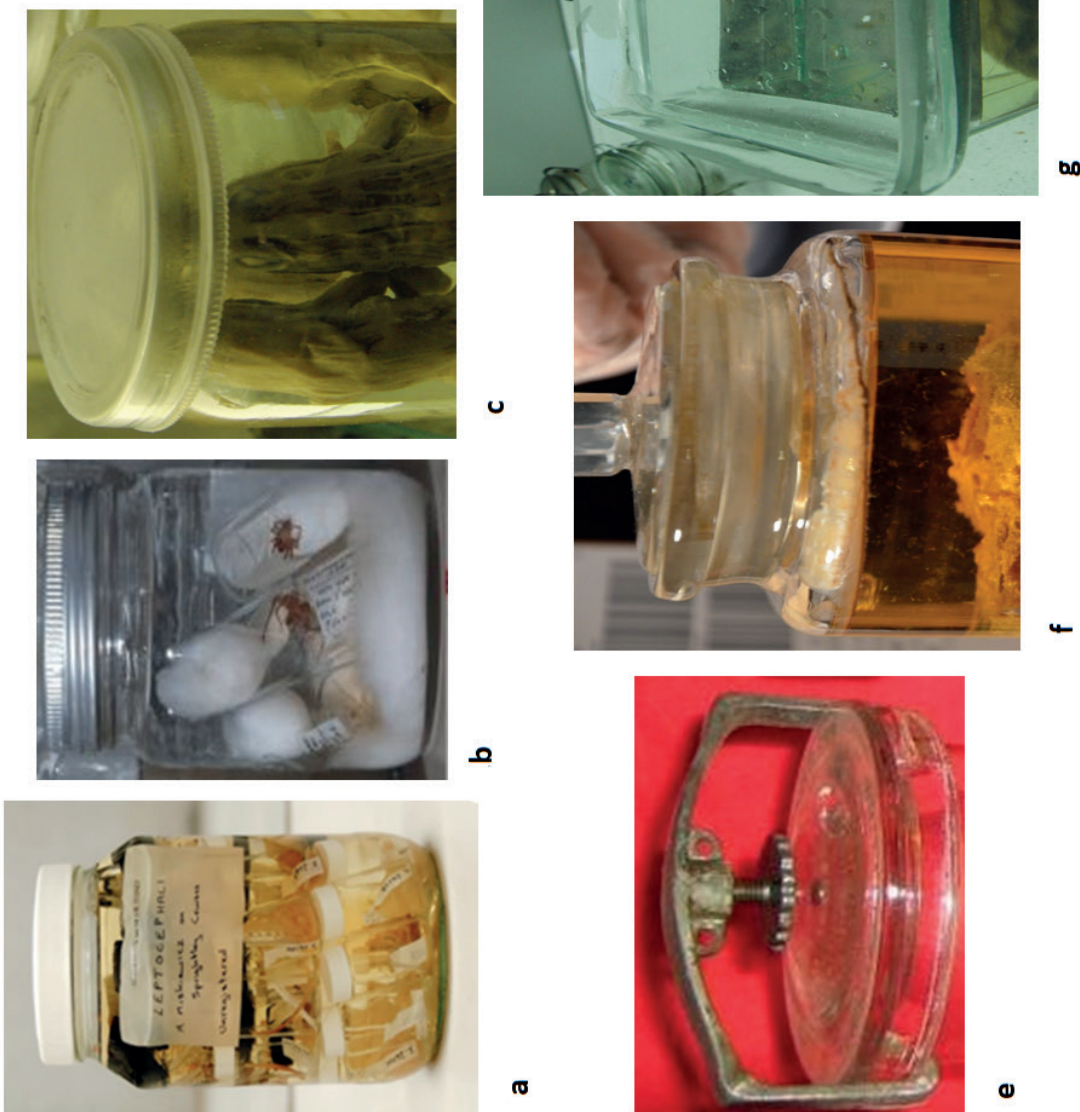

ข

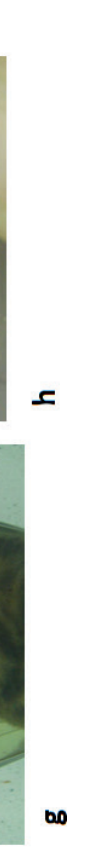



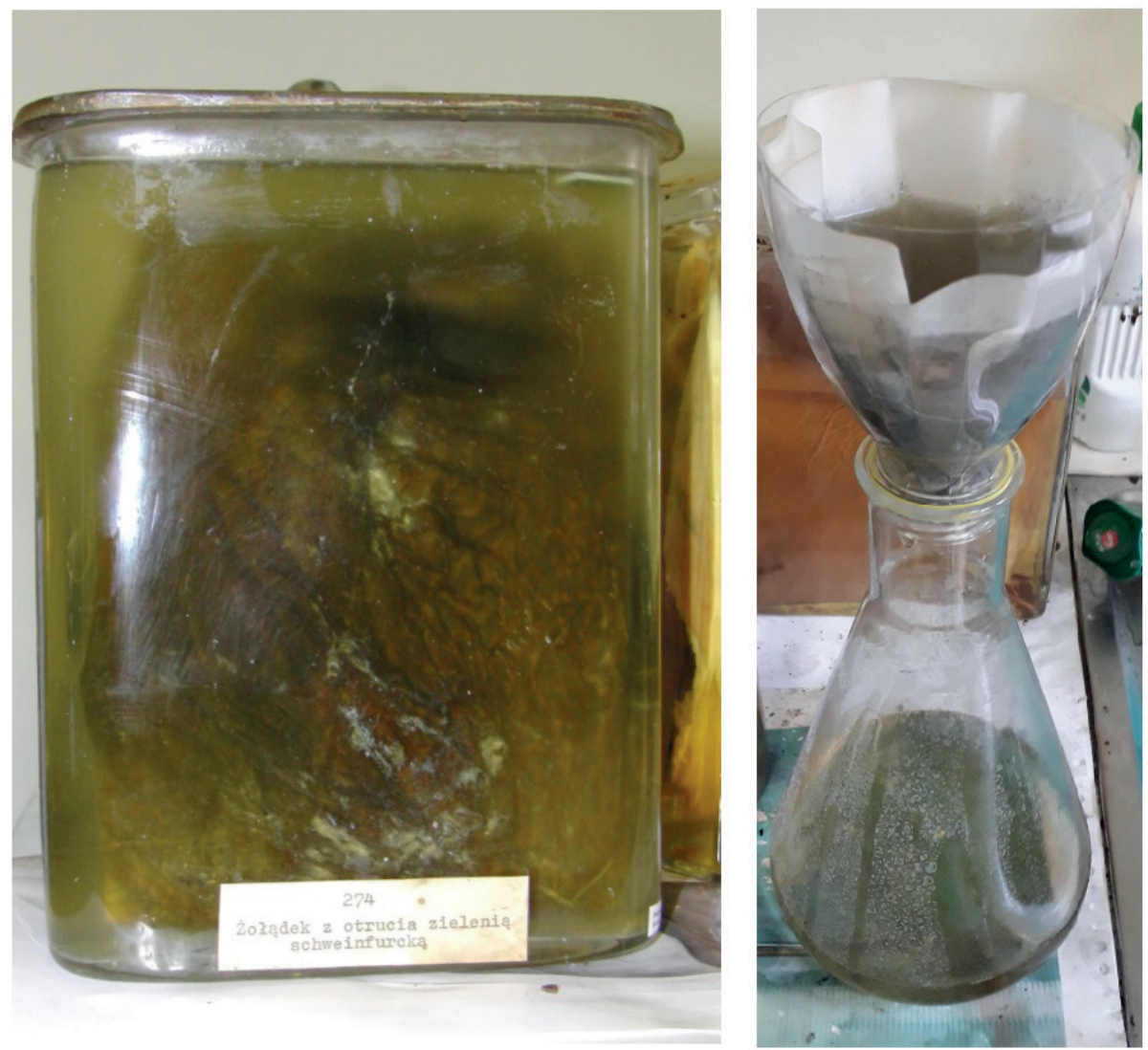

Il. II. Przykład mętnego płynu, który przesączono. Fot. M.J. Czerbak 

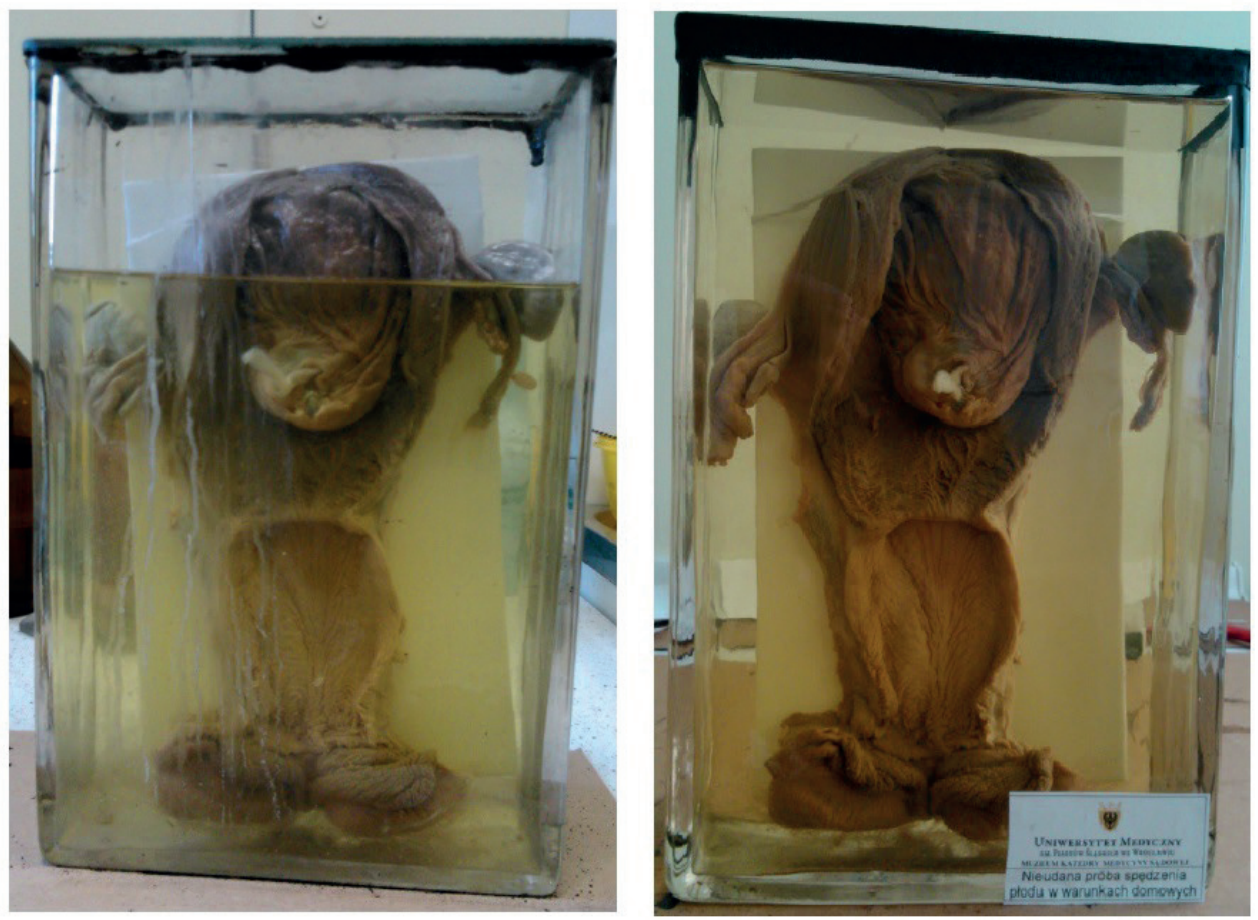

Il. III. Przykład preparatu przed uzupełnieniem płynu konserwującego i po jego uzupełnieniu. Fot. M.J. Czerbak 

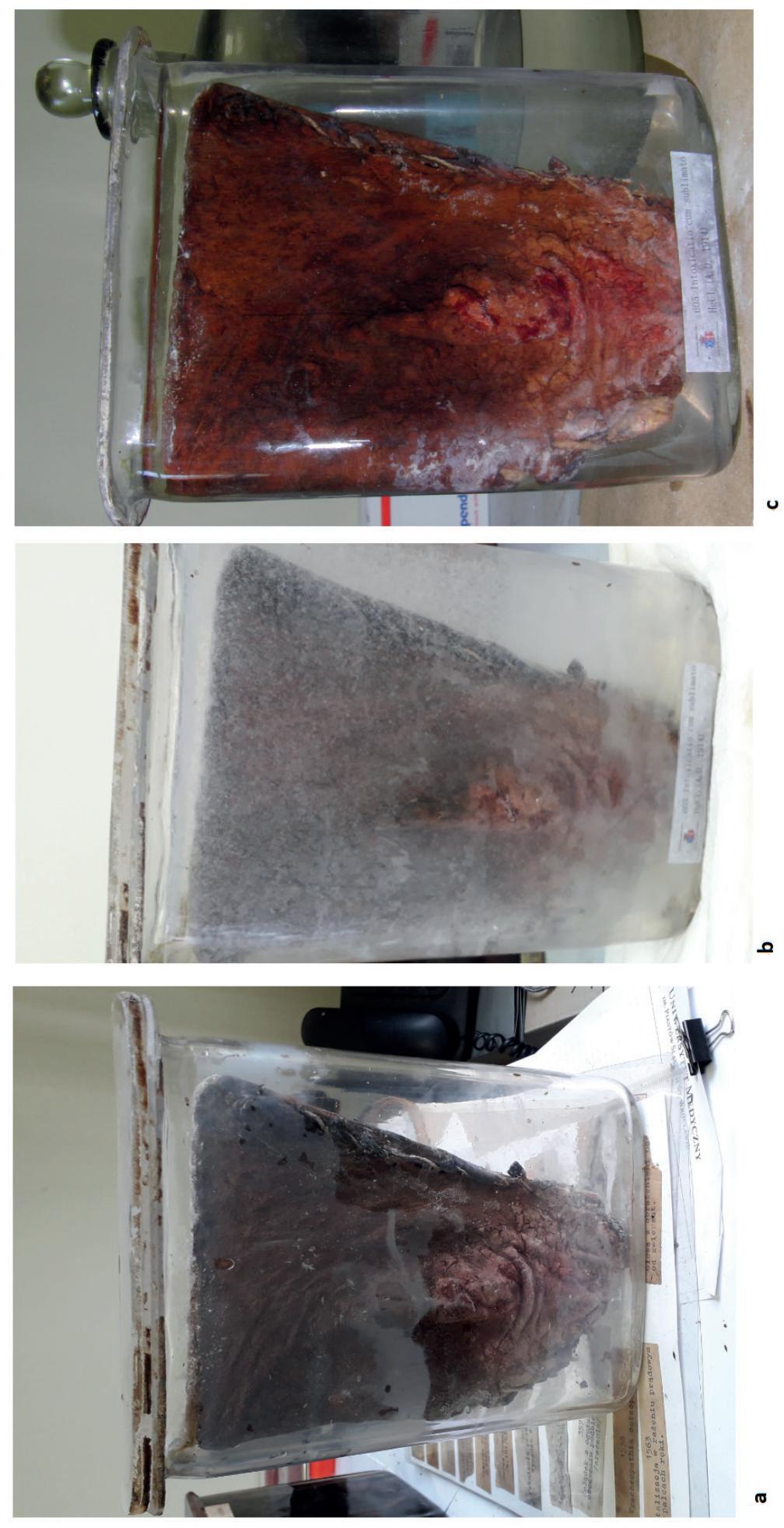

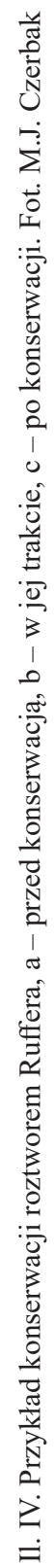




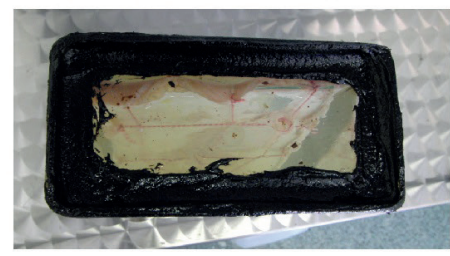

a
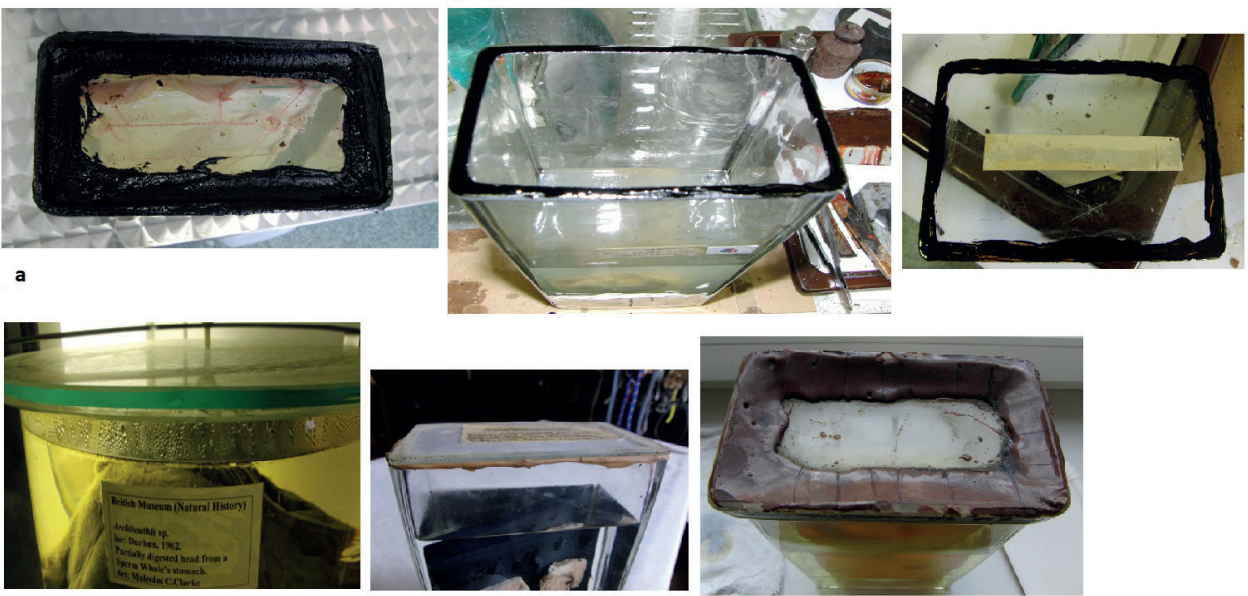

d

b
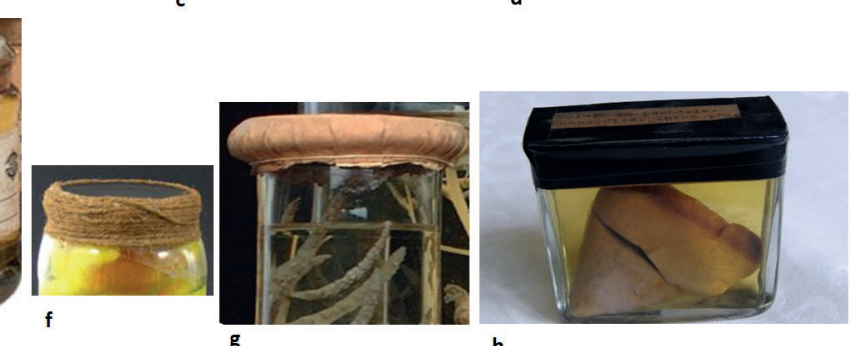

h

e

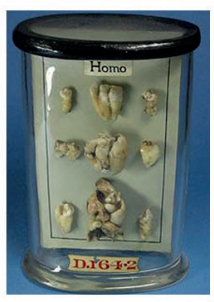

i

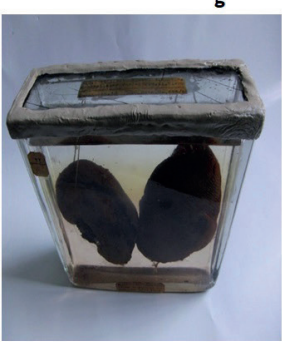

j

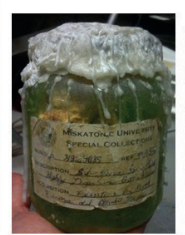

k

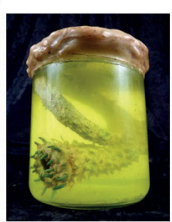

Il. V. Rodzaje uszczelnień: 5a - bitum, b - silikon, c - klej montażowy, d - lak, e - błona zwierzęca, $\mathrm{f}$ - sznurek, g-opaska/tkanina, $\mathrm{h}$ - taśma, $\mathrm{i}$ - pomalowanie, $\mathrm{j}$ - kit szklarski, $\mathrm{k}$ - parafina/wosk pszczeki. Fot. M.J. Czerbak 